\title{
Titanium Dioxide Nanoparticles are not Cytotoxic or Clastogenic in Human Skin Cells
}

Cynthia L Browning ${ }^{1,2,3}$, Therry The ${ }^{1,2}$, Michael D Mason ${ }^{3}$ and John Pierce Wise Sr. ${ }^{1,2,3 *}$

${ }^{1}$ Wise Laboratory of Environmental and Genetic Toxicology, University of Southern Maine, Portland ME 04103, USA

${ }^{2}$ Maine Center for Toxicology and Environmental Health, University of Southern Maine, Portland ME 04103, USA

${ }^{3}$ Graduate School of Biomedical Science and Engineering, University of Maine, Orono ME 04469, USA

\begin{abstract}
The application of nanoparticle technology is rapidly expanding. The reduced dimensionality of nanoparticles can give rise to changes in chemical and physical properties, often resulting in altered toxicity. People are exposed dermally to titanium dioxide $\left(\mathrm{TiO}_{2}\right)$ nanoparticles in industrial and residential settings. The general public is increasingly exposed to these nanoparticles as their use in cosmetics, sunscreens and lotions expands. The toxicity of $\mathrm{TiO}_{2}$ nanoparticles towards human skin cells is unclear and understudied. We used a human skin fibroblast cell line to investigate the cytotoxicity and clastogenicity of $\mathrm{TiO}_{2}$ nanoparticles after $24 \mathrm{~h}$ exposure. In a clonogenic survival assay, treatments of 10,50 and $100 \mu \mathrm{g} / \mathrm{cm}^{2}$ induced $97.8,88.8$ and $84.7 \%$ relative survival, respectively. Clastogenicity was assessed using a chromosomal aberration assay in order to determine whether $\mathrm{TiO}_{2}$ nanoparticles induced serious forms of DNA damage such as chromatid breaks, isochromatid lesions or chromatid exchanges. Treatments of $0,10,50$ and 100 $\mu \mathrm{g} / \mathrm{cm}^{2}$ induced $3.3,3.0,3.0$ and $2.7 \%$ metaphases with damage, respectively. No isochromatid lesions or chromatid exchanges were detected. These data show that $\mathrm{TiO}_{2}$ nanoparticles are not cytotoxic or clastogenic to human skin cells.
\end{abstract}

Keywords: Titanium dioxide; Nanotoxicology; Clastogenicity; Chromosome aberration; Skin fibroblasts

Abbreviations: $\mathrm{TiO}_{2}$ - Titanium dioxide

\section{Introduction}

Nanoparticles are loosely defined as particles with dimensions less than $100 \mathrm{~nm}$. The small volume and large relative surface area of nanoparticle scan give rise to a number of properties that deviate dramatically from those found in their bulky counterparts [1]. These include changes in thermal behavior, material strength, solubility, conductivity, optical properties and catalytic activity [1-3]. A surge of new products containing nanoparticles has resulted from the application of these properties in commercial, industrial and biomedical products. The Project on Emerging Nanotechnologies reports that as of October 2013, 1,628 consumer products contained nanotechnology [4].

The high photocatalytic and super-hydrophilic properties of titanium dioxide $\left(\mathrm{TiO}_{2}\right)$ nanoparticles have made them popular for a wide variety of applications. The current major applications of $\mathrm{TiO}_{2}$ nanoparticles includes; self-cleaning cements, glass and paints; water purification systems; anti-fogging coatings for glass; and as a UVattenuating ingredient in lotions, sunscreens and cosmetics $[5,6]$. Robichaud et al. [7] estimate that the increasing demand for $\mathrm{TiO}_{2}$ nanoparticles will result in the total conversion of the $\mathrm{TiO}_{2}$ industry to nano by 2025 , with an annual production of $\sim 2.5$ million metric tons.

However, the unique properties of $\mathrm{TiO}_{2}$ nanoparticles may alter the way they interact with biological molecules and consequently, their toxicity. While bulky $\mathrm{TiO}_{2}$ particles have traditionally been considered biologically inert, the toxicity of nano-sized $\mathrm{TiO}_{2}$ particles is unclear. The results of studies investigating the genotoxicity of $\mathrm{TiO}_{2}$ nanoparticles are contradictory. In vivo and in vitro studies indicate an increase in oxidative DNA damage, single strand DNA breaks, or micronuclei following exposure to $\mathrm{TiO}_{2}$ nanoparticles [8-13] However, other studies contradict these findings [14-17]. The only clear conclusion from the collective studies on $\mathrm{TiO}_{2}$ toxicity is that the crystalline form, particle size and agglomeration of the nanoparticles all play a crucial role in the determining their toxicity.
While these previous studies have been conducted in a variety of cell types, few studies have investigated the effect of $\mathrm{TiO}_{2}$ nanoparticles after dermal exposure or in human skin cells. Dermal exposure to $\mathrm{TiO}_{2}$ nanoparticles occurs in industrial and residential settings. For example, construction workers and contractors are exposed to $\mathrm{TiO}_{2}$ nanoparticles in cement dust, paints and primers. In a residential setting, people are exposed to $\mathrm{TiO}_{2}$ nanoparticles through the daily application of lotions, sunscreens and cosmetics. Thus, dermal exposure is a significant route of exposure to the general public as sunscreen alone is utilized by more than 200 million Americans [5].

Studies have shown that $\mathrm{TiO}_{2}$ nanoparticles can penetrate the cellular membrane of skin cells [18-21]. Monteiro-Riviere et al [22] showed that UVB-damage enhanced the penetration of $\mathrm{TiO}_{2}$ nanoparticles in sunscreen formulations into the dermal layers. Determining the toxicity of $\mathrm{TiO}_{2}$ nanoparticles in human skin cells is crucial to defining whether they represent a human health concern.

The few studies that have investigated the genotoxicity of $\mathrm{TiO}_{2}$ nanoparticles in human skin cells offer contradictory results. One study showed an increase in DNA strand breaks and oxidative damage after 6 hours exposure to $\mathrm{TiO}_{2}$ nanoparticles, determined by an alkaline Comet assay, with and without Fpg treatment [23]. Other studies found an increase in the activity of key DNA double strand break repair proteins after 24 hours $\mathrm{TiO}_{2}$ nanoparticle exposure, measured by immunofluorescence and western blotting for phosphorylated H2A.X,

*Corresponding author: John Pierce Wise Sr., Wise Laboratory of Environmental and Genetic Toxicology, University of Southern Maine, 178 Science Building, 96 Falmouth Street, Portland ME 04103, USA, Tel: +1 207 228 8050; E-mail: john.wise@usm.maine.edu

Received July 24, 2014; Accepted August 08, 2014; Published September 06 2014

Citation: Browning CL, The T, Mason MD, Wise Sr. JP (2014) Titanium Dioxide Nanoparticles are not Cytotoxic or Clastogenic in Human Skin Cells. J Environ Anal Toxicol 4: 239. doi: 10.4172/2161-0525.1000239

Copyright: (C) 2014 Browning CL, et al. This is an open-access article distributed under the terms of the Creative Commons Attribution License, which permits unrestricted use, distribution, and reproduction in any medium, provided the original author and source are credited. 
phosphorylated ATM and phosphorylated Chk2 [24,25]. However, a third study showed no alteration of the cell cycle and no increase in apoptosis after 24 hours exposure to $\mathrm{TiO}_{2}$ nanoparticles, suggesting that the cell is not halting its cycle to repair DNA damage nor is it inducing death due to such damage [26].

Chromosomal aberrations are a standard component of hazard characterization and are a well-established short term marker for cancer [27]. However, no studies have investigated the ability of $\mathrm{TiO}_{2}$ nanoparticles to induce chromosomal aberrations in human skin cells. Thus, the purpose of this study was to investigate the ability of $\mathrm{TiO}$ nanoparticles to induce clastogenicity, expressed as chromosomal aberrations in human skin fibroblasts.

\section{Materials and methods}

\section{Chemicals and reagents}

DMEM and Ham's F12 50:50 mixture and GlutaGRO (L-alanylL-glutamine solution) were purchaed from Mediatech Inc (Herndon, VA). Cosmic Calf Serum was purchased from Hyclone (Logan, UT). All plasticware was purchased from BD Biosciences (Franklin Lakes, NJ). Dulbecco's phosphate buffered saline (PBS), Gurr's buffer, penicillin/ streptomycin, sodium pyruvate and trypsin/EDTA were purchased from Life Technologies (Grand Island, NY). Crystal violet, calcium chloride, demecolchicine, lead chromate $\left(\mathrm{PbCrO}_{4}\right)$ and potassium chloride were purchased from Sigma-Aldrich (St. Louis, MO). Acetic acid and methanol were purchased from J.T. Baker (Phillipsburg, NJ). Giemsa stain was purchased from Biomedical Specialties Inc. (Santa Monica, CA). Titanium dioxide nanoparticles, Aeroxide $\mathrm{TiO}_{2}$ P25, were purchased from Nippon Aerosil Co, LTD (Tokyo, Japan). Microscope slides and cytoseal 60 slide mounting medium were purchased from Thermo Fisher Scientific Inc. (Waltham, MA). Ethyl alcohol, Embed-812 kit, flat embedding mold, gluteraldehyde, osmium tetra oxide, sodium cacodylate, sodium maleate and uranyl acetate were purchased from EMS (Hatfield, PA).

\section{Cell culture}

For these studies we used primary human skin fibroblasts (BJ cells) and human skin fibroblast cells immortalized with hTERT (BJhTERT cells) previously described in Vaziri and Benchimol [28]. Cells were cultured as adherent monolayers of cells in DMEM/F12 50:50 mixture, supplemented with $15 \%$ cosmic calf serum, $2 \mathrm{mM}$ GlutaGRO, $100 \mathrm{U} /$ $\mathrm{ml}$ penicillin $/ 100 \mu \mathrm{g} / \mathrm{ml}$ streptomycin and $0.1 \mathrm{mM}$ sodium pyruvate and subcultured at least once a week. Cells were maintained in a 5\% $\mathrm{CO}_{2}$ - humidified environment at $37^{\circ} \mathrm{C}$.

\section{Nanoparticle preparation and exposure}

The $\mathrm{TiO}_{2}$ nanoparticles utilized were Aeroxide $\mathrm{TiO}_{2} \mathrm{P} 25$, which have been used in many previous studies $[10,12,20,25,29,30]$. The $\mathrm{TiO}_{2}$ nanoparticles were $25 \mathrm{~nm}$ in size and spherical in shape with a zeta potential of $-36.4 \mathrm{mV}$ as determined by dynamic light scattering (DLS) and transmission electron micrograph (TEM). The crystalline composition of Aeroxide $\mathrm{TiO}_{2} \mathrm{P} 25$ nanoparticles has been shown to vary between $78-85 \%$ anatase, $14-17 \%$ rutile and $0-13 \%$ amorphous [31] and the surface area has been reported as $46 \mathrm{~m}^{2} / \mathrm{g}$ [10]. The nanoparticles were uncoated and received no physical modification after purchase.

$\mathrm{TiO}_{2}$ nanoparticles were suspended in deionized water at a concentration of $50 \mathrm{mg} / \mathrm{ml}$. The nanoparticles were probe sonicated (Misonix Sonicator Ultrasonic Processor XL) at $10 \mathrm{KHz}$ for $5 \mathrm{~min}$ directly prior to dilution to ensure an even distribution of the nanoparticles. Dilutions were prepared in cold deionized water filtered with a $0.22 \mu \mathrm{m}$ filter. Cells were treated with $\mathrm{TiO}_{2}$ nanoparticles in low light conditions and incubated in the dark throughout each experiment. Lead chromate (CAS\# 7758-97-6, ACS reagent minimum 98\% purity), was used as a positive control and administered as a suspension of micro-particles as previously described [32].

The concentrations of $\mathrm{TiO}_{2}$ nanoparticles utilized in this study are representative of real-world exposure. The Skin Cancer Foundation reports that most people use one quarter the recommended amount $(30 \mathrm{ml})$ of sunscreen [33]. Most sunscreens contain 2-15\% $\mathrm{TiO}$ nanoparticles [5]. If a person applies $7.5 \mathrm{ml}$ of sunscreen containing $2 \% \mathrm{TiO}_{2}$ nanoparticles $(20 \mathrm{mg} / \mathrm{ml})$, they are exposed to $150 \mathrm{mg}$ of nanoparticles. Considering that this volume would be spread over the surface of the skin, each cell would be exposed to a smaller percentage of $\mathrm{TiO}_{2}$ nanoparticles. At $1 \%$ of the total, each cell would be exposed to $200 \mu \mathrm{g} / \mathrm{ml} \mathrm{TiO}_{2}$ nanoparticles, which is the mid-point of our concentration range $(0-423 \mu \mathrm{g} / \mathrm{ml})$. Additionally, Prasad et al. [24] calculated that the average skin exposure to $\mathrm{TiO}_{2}$ nanoparticles from sunscreen application would range from $25-75 \mu \mathrm{g} / \mathrm{cm}^{2}$, further validating our range of concentrations $\left(0-100 \mu \mathrm{g} / \mathrm{cm}^{2}\right)$.

\section{Characterization of $\mathrm{TiO}_{2}$ nanoparticles}

A transmission electron micrograph (TEM) image was taken of the $\mathrm{TiO}_{2}$ nanoparticles in water prior to treatment. To characterize the size of the $\mathrm{TiO}_{2}$ nanoparticles under experimental conditions, 90,000 cells were seeded into $2.3 \mathrm{ml}$ cell culture medium per well of 6-well plates $\left(9.5 \mathrm{~cm}^{2}\right.$ surface area per well). Cells were allowed to rest for 48 hours to enter $\log$ phase growth before treatment with $0,10,50$ or $100 \mu \mathrm{g} / \mathrm{cm}^{2}$ $\mathrm{TiO}_{2}$ nanoparticles. After 24 hours incubation, the extracellular medium was collected. $\mathrm{TiO}_{2}$ nanoparticle suspensions were characterized in solution by dynamic light scattering (DLS) using a Malvern NanoZS where particle size distributions were determined on the basis of number, volume and scattering intensity. DLS measurements were also taken for $\mathrm{TiO}_{2}$ nanoparticle suspensions in complete media (serumcontaining) and media without serum, without cells present.

\section{Cytotoxicity assay}

Cytotoxicity was assessed using a clonogenic survival assay based on our published methods [32]. Briefly, 90,000 cells were seeded into $2.3 \mathrm{ml}$ cell culture medium per well of 6 -well plates $\left(9.5 \mathrm{~cm}^{2}\right.$ surface area per well). Cells were allowed to enter log phase growth and were treated $\mathrm{TiO}_{2}$ nanoparticles or lead chromate (positive control) for 24 hours. Following treatment, cells were harvested, counted and reseeded at a density of 2,000 cells per $100 \mathrm{~mm}$ dish (4 dishes per treatment). Cells were allowed to grow to form colonies. Once colonies formed, they were stained with crystal violet and counted. At least 3 independent experiments were conducted.

\section{Clastogenicity assay}

Clastogenicity was assessed by measuring chromosomal aberrations according to our published methods [32] . 500,000 cells were seeded into $13 \mathrm{ml}$ cell culture medium in $100 \mathrm{~mm}$ dishes $\left(55 \mathrm{~cm}^{2}\right.$ surface area per dish). Cells were allowed to rest for 48 hours to enter log phase growth, followed by treatment with $\mathrm{TiO}_{2}$ nanoparticles or lead chromate (positive control) for 24 hours. One hour prior to the end of treatment, demecolcine was added to arrest cells in metaphase. Cells were then harvested, swollen with $0.075 \mathrm{M} \mathrm{KCl}$ for $17 \mathrm{~min}$ and fixed with 3:1 methanol : acetic acid. Cells were then dropped on clean, wet slides and scored for chromosome abberrations. Three independent experiment 
were conducted and 100 metaphases were analyzed for each treatment. Chromosome aberrations were scored using a previously defined criteria [32]. DNA damage was expressed as the percent of metaphases with damage and as total aberrations which considers the metaphase and each chromosome as the unit, respectively.

\section{Uptake of $\mathrm{TiO}_{2}$ nanoparticles}

The intracellular uptake of $\mathrm{TiO}_{2}$ nanoparticles was confirmed with TEM imaging. A monolayer of cells was treated with $50 \mu \mathrm{g} / \mathrm{cm}^{2}$ $\mathrm{TiO}_{2}$ nanoparticles for 24 hours. After treatment, cells were harvested, pelleted and resuspended with $5 \%$ gluteraldehyde in $0.1 \mathrm{M}$ sodium cacodylate buffer for 2 hours. After washing twice with cacodylate buffer, the cell pellet was encapsulated with sodium alginate and calcium chloride, post-fixed with $1 \%$ osmium tetraoxide in cacodylate buffer for 2 hours, washed with sodium maleate and stained in $0.5 \%$ uranyl acetate for 2 hours in the dark. Cells were then dehydrated with graded ethanol (50\% to $100 \%)$, followed by propylene oxide. Finally, propylene oxide was gradually replaced with EMbed 812, embedded and cured at $60^{\circ} \mathrm{C}$ overnight. $30-40 \mathrm{~nm}$ sections were stained with uranyl acetate and lead citrate for contrast and examined with Zeis/ LEO 922 Omega Transmission Electron Microscope at 100 to $120 \mathrm{kV}$.

\section{Statistical analysis}

Results were expressed as mean +/- SE of three independent experiments. Standard errors for each mean value were calculated based on the unbiased estimate of variance. Differences among means were evaluated using a Student's t-test and 95\% confidence limits. The criterion for statistical significance was $p<0.05$. All analyses were conducted using GraphPad QuickCalcs.

\section{Results}

$\mathrm{TiO}_{2}$ nanoparticle aggregation size increases in a concentration-dependent manner

To determine the size of the agglomerated $\mathrm{TiO}_{2}$ nanoparticles that the cells would be exposed to, the size distribution of the nanoparticle agglomerations was measured in the extracellular medium of cells treated with 10,50 or $100 \mu \mathrm{g} / \mathrm{cm}^{2} \mathrm{TiO}_{2}$ nanoparticles using dynamic light scattering (DLS) and analyzed based on the number distribution. The peak distribution of $\mathrm{TiO}_{2}$ nanoparticle agglomeration was less than $100 \mathrm{~nm}$ when cells were treated with $10 \mu \mathrm{g} / \mathrm{cm}^{2} \mathrm{TiO}_{2}$ nanoparticles. However, the distribution showed a peak at $225 \mathrm{~nm}$ when cells were treated with $50 \mu \mathrm{g} / \mathrm{cm}^{2} \mathrm{TiO}_{2}$ nanoparticles and there was a broad size distribution from $150 \mathrm{~nm}$ to $500 \mathrm{~nm}$ when cells were treated with $100 \mu \mathrm{g} / \mathrm{cm}^{2} \mathrm{TiO}_{2}$ nanoparticles (Figure $1 \mathrm{~A}$ ). The $\mathrm{TiO}_{2}$ aggregates were comprable in size in the complete medium and the extracellular medium while they were larger in the serum-free media (Figure 1B).

\section{$\mathrm{TiO}_{2}$ nanoparticles are not cytotoxic to human skin fibroblasts}

$\mathrm{TiO}_{2}$ nanoparticles did not induce cytotoxicity in human skin fibroblasts. In the clonogenic survival assay, treatments of 10, 50 and $100 \mu \mathrm{g} / \mathrm{cm}^{2}$ induced $97.8,88.8$ and $84.7 \%$ relative survival (percent of control), respectively (Figure 2A). There was no significant difference between the relative survival of the treated cells and the control cells. Cell survival was also evidenced by cell counts after 24 hours $\mathrm{TiO}_{2}$ treatment. Treatments of 10,50 and $100 \mu \mathrm{g} / \mathrm{cm}^{2}$ induced 99.4, 123.8 and $112.1 \%$ relative cell counts (percent of control), respectively (Figure 2B).These results were confirmed in primary human skin fibroblasts. In contrast, $0.5 \mu \mathrm{g} / \mathrm{cm}^{2}$ lead chromate (positive control) induced $0.9 \%$ relative survival in the clonogenic assay and $80.3 \%$ relative cell count, indicating that the assays were functional (data not shown).

$\mathrm{TiO}_{2}$ nanoparticles are not clastogenic to human skin fibroblasts

$\mathrm{TiO}_{2}$ nanoparticles did not induce clastogenicity, measured as chromosomal aberrations, in human skin fibroblasts (Figure 3). Treatments of $0,10,50$ and $100 \mu \mathrm{g} / \mathrm{cm}^{2}$ induced 3.3, 3.0, 3.0 and $2.7 \%$ metaphases with damage, respectively. The same amount of damage was observed when represented as total abberrations in 100 metaphases. There was no significant difference between the chromosomal damage of the treated cells and the control cells. No isochromatid lesions or chromatid exchanges were identified during the chromosomal analysis. These results were confirmed in primary human skin fibroblasts. The positive control, $0.5 \mu \mathrm{g} / \mathrm{cm}^{2}$ lead chromate, indicated that our assay was functional as it induced $29.7 \%$ metaphases with damage and 44 total aberrations (data not shown).
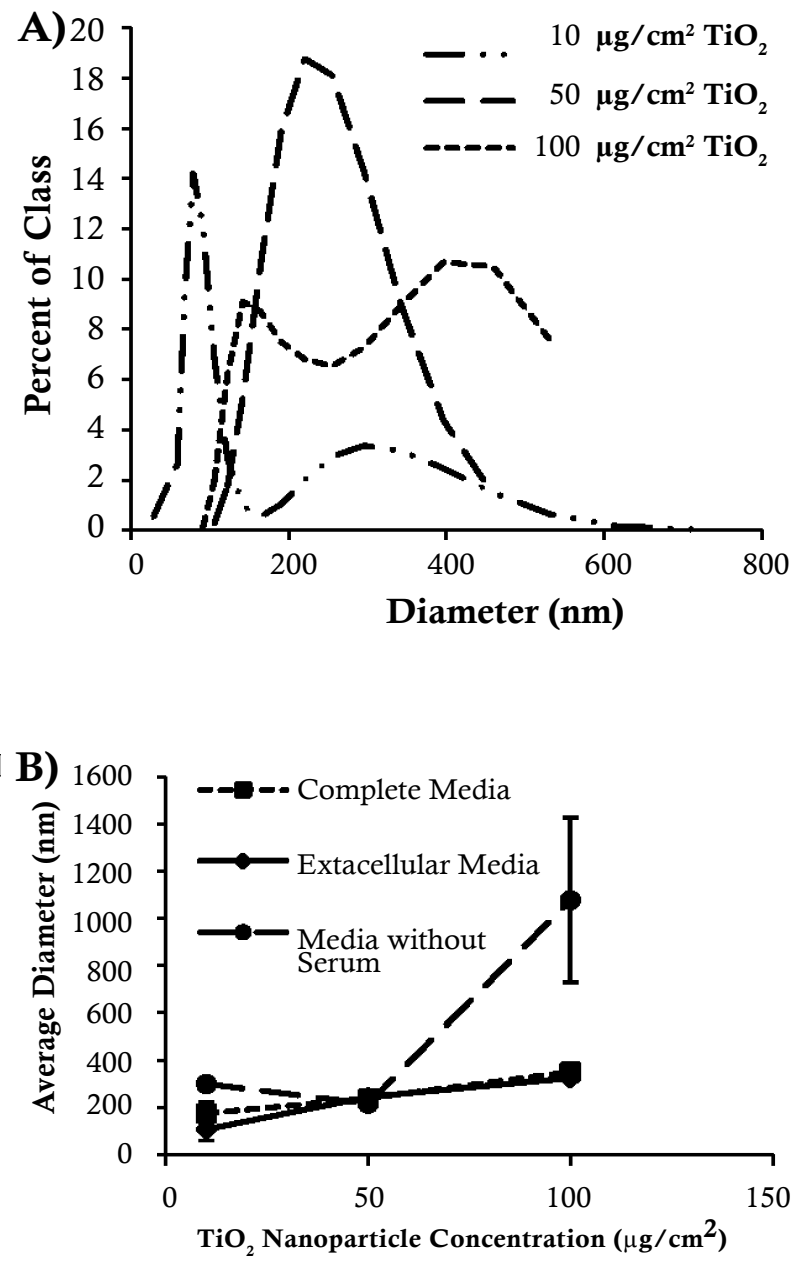

Figure 1: Titanium dioxide nanoparticle size distributions based on DLS. This figure shows that the average size distribution of agglomerated $\mathrm{TiO}_{2}$ nanoparticles increases in a concentration dependent manner. Data represent the mean of 3 independent experiments $+/$ - standard error of the mean.

A. Comparison of the size distributions of $\mathrm{TiO}_{2}$ nanoparticles in extracellular media.

B. Comparison of the average diameter of $\mathrm{TiO}_{2}$ nanoparticles aggregates in extracellular media, complete media and media without serum. 

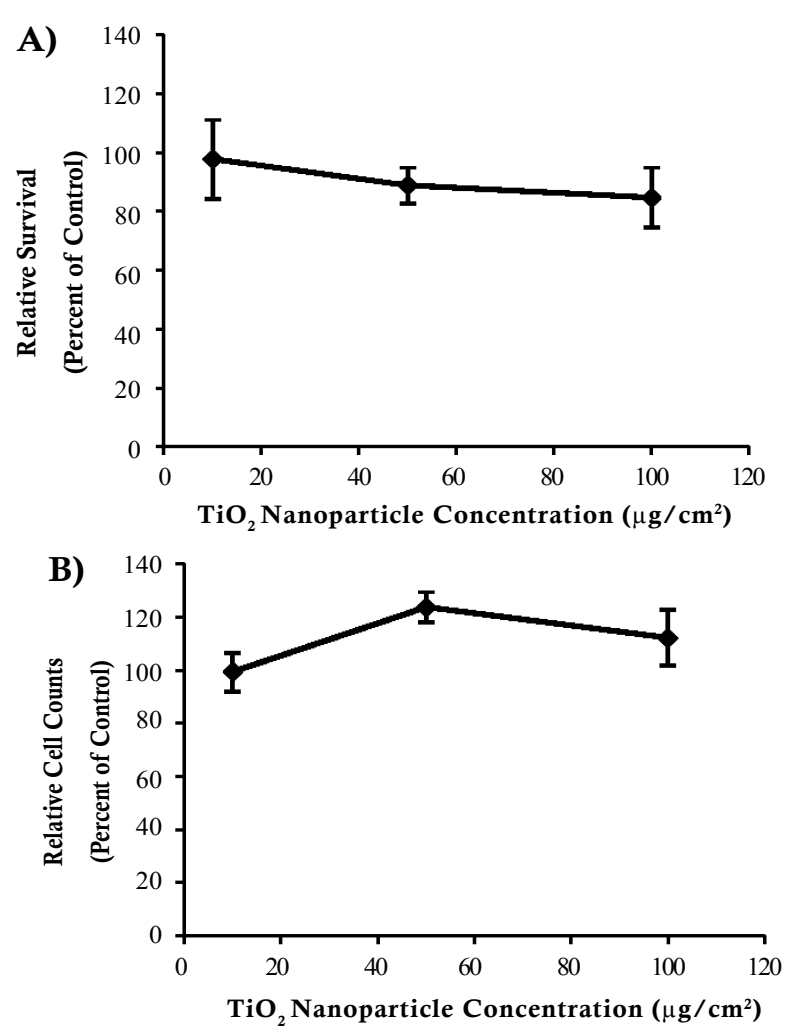

Figure 2: $\mathrm{TiO}_{2}$ nanoparticles were not cytotoxic to human skin fibroblasts. This figure shows that $\mathrm{TiO}_{2}$ nanoparticles did not induce cytotoxicity in human skin fibroblasts measured by a clonogenic survival assay. A. cell count. B. Data represent the mean of 3 independent experiments $+/$ - standard error of the mean.

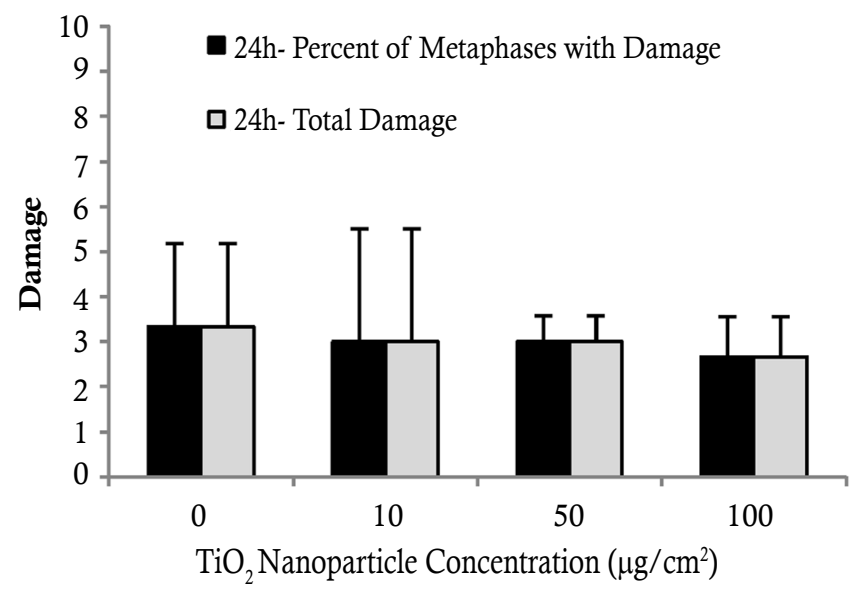

Figure 3: $\mathrm{TiO}_{2}$ nanoparticles were not clastogenic to human skin fibroblasts. This figure shows that $\mathrm{TiO}_{2}$ nanoparticles did not induce chromosomal aberrations in human skin fibroblasts. Data represent the mean of 3 independent experiments +/- standard error of the mean.

\section{$\mathrm{TiO}_{2}$ nanoparticles are internalized by human skin fibroblasts}

TEM imaFging showed that $\mathrm{TiO}_{2}$ nanoparticles were internalized by human skin fibroblasts (Figure $4 \mathrm{~A}$ ). $\mathrm{TiO}_{2}$ nanoparticles were identified in the cytoplasm, often associated with lysosomes (Figure $4 \mathrm{~B}$ ), and in the nucleus (Figure 4C).

\section{Discussion}

$\mathrm{TiO}_{2}$ nanoparticles are widely utilized for their unique superhydrophilic and photocatalytic properties. In addition to industrial exposure through cement dusts, paints and primers, the general public is exposed to $\mathrm{TiO}_{2}$ nanoparticles through its inclusion in various personal products. $\mathrm{TiO}_{2}$ nanoparticles are utilized in sunscreens, cosmetics and lotions resulting in daily dermal exposure. For example, it is estimated that 33 million Americans use sunscreen daily and another 177 million people use it occasionally [5]. However, the toxicity of $\mathrm{TiO}_{2}$ nanoparticles in skin cells is understudied and not well defined.

To our knowledge, this is the first study to measure the ability of $\mathrm{TiO}_{2}$ nanoparticles to induce chromosome aberrations in a human cell line. Our data show no significant increase in aberrations after 24 hours exposure. This result is consistent with previously published studies that found $\mathrm{TiO}_{2}$ nanoparticles did not induce chromosome aberrations in $\mathrm{CHO}$ cells $[15,17]$. Previous studies that have measured genotoxicity with other assays further support this finding. $\mathrm{TiO}_{2}$ nanoparticles did not induce a significant increase in DNA strand breaks in human lung epithelial cells, lung fibroblasts or lymphoblasts, measured by Comet assay $[11,14,16,29]$.

DNA double strand breaks are a serious form of DNA damage that can lead to chromosomal aberrations if they are not repaired before the cell enters mitosis. Jugan et al. [10] showed that $\mathrm{TiO}_{2}$ nanoparticles do not induce DNA double strand breaks, measured as phosphorylated H2A.X. In agreement with this, another study indicated no response of the DNA double strand break repair proteins, ATM and RAD51after $\mathrm{TiO}_{2}$ exposure [16]. In contrast, however, other studies show a concentration-dependent increase in DNA double strand breaks, measured as phosphorylated H2A.X and the activation of the DNA double strand break repair proteins, ATM and Chk2 $[24,25]$. It is important to note that the phosphorylation of H2A.X is an indirect measure of DNA double strand breaks. From one perspective, phosphorylated H2A.X represents an early event in the DNA double strand break repair signaling pathway [34]. Therefore, an increase in the phosphorylation of H2A.X indicates the activation of this repair pathway. If $\mathrm{TiO}_{2}$ nanoparticles induce DNA double strand breaks, the activation of DNA double strand break repair would prevent this damage from causing genomic alterations or chromosomal aberrations. Our data suggest that, if this repair perspective is correct, any DNA breaks formed after 24 hours $\mathrm{TiO}_{2}$ nanoparticle exposure are successfully repaired before they manifest as chromosomal aberrations.

An alternative perspective for phosphorylated H2A.X is that it also serves as a marker of senescence [35]. Thus, rather than measuring breaks, the H2A.X foci or some fraction of them, may actually reflect senescent cells. This possibility is consistent with the observed differences in cytotoxicity between the two studies measuring H2A.X, with one measuring increased phosphorylated H2A.X thus finding increased senescence and consequently an increase in their apparent cytotoxicity measures and the other finding no increase in H2A.X and no toxicity $[10,24]$. If this possibility were correct, it would be consistent with our observations of no chromosome damage in skin cells and others observations of no DNA damage when using direct measures of damage in other cell types $[11,14,15,16,17,29]$.

Our data showed that $\mathrm{TiO}_{2}$ nanoparticles did not induce 
A)

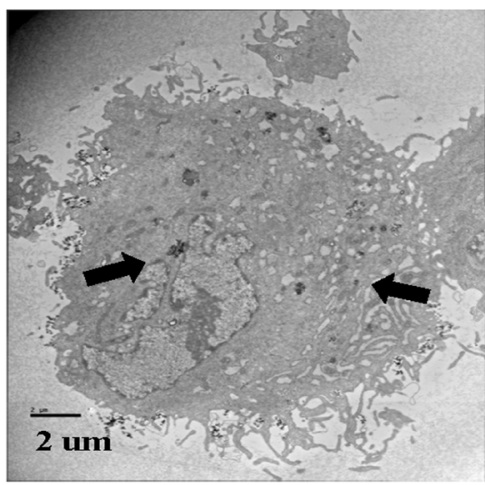

B)

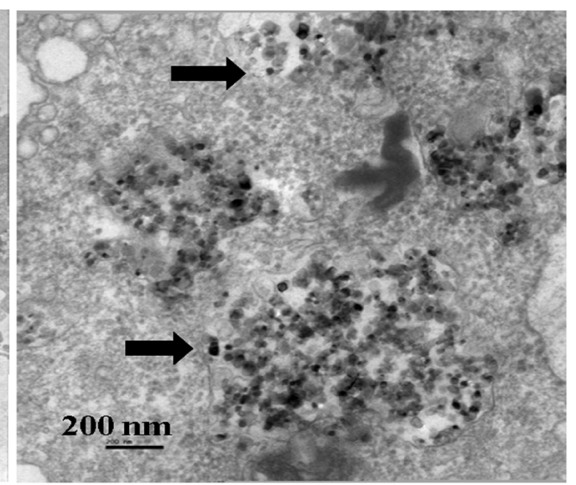

C)

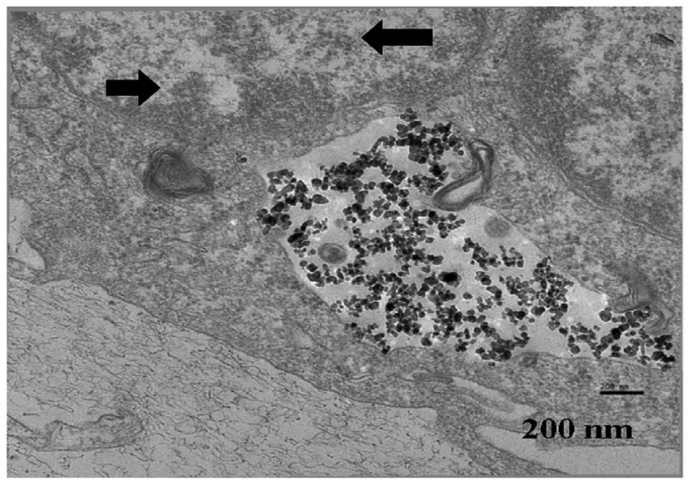

Figure 4: $\mathrm{TiO}_{2}$ nanoparticles were internalized by human skin fibroblasts

This figure shows that $\mathrm{TiO}_{2}$ nanoparticles were internalized by human skin fibroblasts shown by $\mathrm{TEM}$ imaging. The black arrows indicate $\mathrm{TiO}_{2}$ nanoparticle aggregates within different subcellular compartments.

A. TEM image showing $\mathrm{TiO}_{2}$ nanoparticles located throughout the entire cell $(4,000 \mathrm{X})$.

B. TEM image showing different sizes of $\mathrm{TiO}_{2}$ nanoparticle aggregates within the cytoplasm $(10,000 \mathrm{X})$.

C. TEM image showing $\mathrm{TiO}_{2}$ nanoparticles within the nucleus $(10,000 \mathrm{X})$.

cytotoxicity after 24 hours exposure. This outcome is consistent for $\mathrm{TiO}_{2}$ nanoparticles when determined by a clonogenic survival assay, as we used in our study $[10,29]$. Our results are also in agreement with other reports that found no significant decrease in cell survival after 24 hours exposure in human lung epithelial cells (A549 and BEAS2B) and lung fibroblasts, measured with SRB, Trypan blue or the MTT assay $[9,14,16]$.

In contrast, several studies have shown that $\mathrm{TiO}_{2}$ nanoparticles induce cell death measured by Trypan blue or the MTT assay in human skin fibroblasts, epidermal (A431) and bronchial epithelial cells (BEAS2B) $[8,23,24]$. Magdolenova et al. [29] suggested that the method of dispersing the nanoparticles prior to treatment may affect the resulting toxicity. In their study, two different methods of dispersal were utilized that resulted in (1) a stable dispersion of $\mathrm{TiO}_{2}$ nanoparticles and (2) an unstable dispersion of $\mathrm{TiO}_{2}$ nanoparticles with a larger agglomerate size. The unstable dispersion induced cytotoxicity in monkey kidney fibroblasts (Cos-1), while the stable dispersion did not.

Interestingly, one previous study has utilized two different cytotoxicity assays in the same cell line after exposure to the same $\mathrm{TiO}_{2}$ nanoparticles and obtained different results [10]. The study measured cytotoxicity in lung epithelial cells (A549) after exposure to $\mathrm{TiO}_{2}$ nanoparticles varying in range from $12-140 \mathrm{~nm}$. After 48 hours exposure, they reported a significant decrease in cell viability measured by the MTT assay, but no significant decrease measured by a clonogenic proliferation assay. Although the results of the MTT assay were significant, the authors note that even the most cytotoxic $\mathrm{TiO}_{2}$ nanoparticles induced less than $25 \%$ cell death [10]. It is interesting that the significant result of the MTT assay did not represent a large decrease in cell viability.

The clonogenic survival assay is a gold standard among cytotoxicity assays. As it depends on the survival and proliferation of cells, it is more sensitive than the other cytotoxicity assays mentioned above [36]. Therefore, the clonogenic survival assay should be more frequently included in the hazard characterization of $\mathrm{TiO}_{2}$.

One might consider that the differences between our results and the previous study conducted in skin cells are due to a difference in cell line. Our skin fibroblasts were immortalized with hTERT, while the previous study used primary skin fibroblasts [24]. It seems unlikely that the hTERT would have much of an effect on the results as previous data show hTERT immortalization does not affect the cellular response to particulate metal exposure [37]. In addition, we did confirm our results in primary skin fibroblasts and found the same outcome (data not shown).

In our study, the $\mathrm{TiO}_{2}$ nanoparticles agglomerated to form aggregates up to twenty times larger than the original nanoparticle size of $25 \mathrm{~nm}$. The concentration-dependent increase in $\mathrm{TiO}_{2}$ nanoparticle aggregation was observed in all sample types and therefore cannot be due to a cellular mechanism. The $\mathrm{TiO}_{2}$ aggregates were nearly identical in size in the complete medium and the extracellular medium while they were larger in the serum-free media. Previous studies have shown that the presence of serum inhibits the aggregation of $\mathrm{TiO}_{2}$ and other nanoparticles $[30,38]$. These results indicate that even though the $\mathrm{TiO}_{2}$ nanoparticles were sonicated directly before treatment in order to evenly disperse the nanoparticles, the cells are subjected to $\mathrm{TiO}_{2}$ nanoparticle agglomerations of increasing size in a concentrationdependent manner.

It has previously been recognized that data characterizing nanoparticles is crucial in order to compare results of different studies $[39,40]$. However, most studies only characterize nanoparticles at one concentration. Our findings suggest that nanoparticle characterization at the lowest and highest concentrations would enhance our interpretation of toxicity data by providing the range of agglomeration present.

Our data showed that $\mathrm{TiO}_{2}$ nanoparticles can penetrate into in the cytoplasm and nucleus of human skin fibroblast cells after 24 hours exposure. These results are in agreement with previous in vitro studies $[18,19]$. Considered together, the results of this study indicate that $\mathrm{TiO}_{2}$ nanoparticles do not induce cytotoxicity or chromosomal aberrations after 24 hours exposure, even though they penetrate both the cellular and nuclear membranes. 
Citation: Browning CL, The T, Mason MD, Wise Sr. JP (2014) Titanium Dioxide Nanoparticles are not Cytotoxic or Clastogenic in Human Skin Cells. J Environ Anal Toxicol 4: 239. doi: 10.4172/2161-0525.1000239

Page 6 of 6

Real-world dermal exposure to $\mathrm{TiO}_{2}$ nanoparticles most likely occurs for periods of time less than that utilized in this study (24 hours). Workers exposed to $\mathrm{TiO}_{2}$ nanoparticles in cement dust and paints probably wash this from their skin within 24 hours. Likewise, sunscreens, lotions and cosmetics are usually washed from the skin with a day. However, dermal exposure to $\mathrm{TiO}_{2}$ nanoparticles is repetitive with many people enduring subsequent exposures on a daily basis. Future studies are needed to determine the effects of repeated, short-term exposure to $\mathrm{TiO}_{2}$ nanoparticles.

\section{Acknowledgement}

We would like to thank Shouping Huang, Sanjeev Kandpal, Christy Gianios, Jr. and Amie Holmes for administrative and / or technical guidance. This work was supported by ARO grant \#W911NF-09-1-0296 (J.P.W.) and NIH grant \#ES016893 (J.P.W.). The content is solely the responsibility of the authors and does not necessarily represent the official views of the National Institute of Health.

\section{References}

1. Banfield JF, Zhang $\mathrm{H}$ (2001) Nanoparticles in the environment. Rev Mineral Geochem 44: 1-58.

2. Burleson DJ, Driessen MD, Penn RL (2004) On the characterization of environmental nanoparticles. J Environ Sci Health A Tox Hazard Subst Environ Eng 39: 2707-2753.

3. Kamat PV (2002) Photophysical, photochemical and photocatalytic aspects of metal nanoparticles. J Phys Chem 106: 7729-7744.

4. Project on Emerging Nanotechnologies (2013) Inventory finds increase in consumer products containing nanoscale materials.

5. Davis J, Long TC, Shatkin JA (2010) Nanomaterial case studies: Nanoscale titanium dioxide in water treatment and in topical sunscreen. EPA/600/R09/057F, U.S. Environmental Protection Agency, Research Triangle Park, NC.

6. Fujishima A, Rao TN, Tryk DA (2000) Titanium dioxide photocatalysis. J Photochem Photobiol C 1-21.

7. Robichaud CO, Uyar AE, Darby MR, Zucker LG, Wiesner MR (2009) Estimates of upper bounds and trends in nano-TiO2 production as a basis for exposure assessment. Environ Sci Technol 43: 4227-4233.

8. Falck GC, Lindberg HK, Suhonen S, Vippola M, Vanhala E, et al. (2009) Genotoxic effects of nanosized and fine TiO2. Hum Exp Toxicol 28: 339-352.

9. Gurr JR, Wang AS, Chen CH, Jan KY (2005) Ultrafine titanium dioxide particles in the absence of photoactivation can induce oxidative damage to human bronchial epithelial cells. Toxicology 213: 66-73.

10. Jugan ML, Barillet S, Simon-Deckers A, Herlin-Boime N, Sauvaigo S, et al (2012) Titanium dioxide nanoparticles exhibit genotoxicity and impair DNA repair activity in A549 cells. Nanotoxicology 6: 501-513

11. Msiska Z, Pacurari M, Mishra A, Leonard SS, Castranova V, et al. (2010) DNA double-strand breaks by asbestos, silica, and titanium dioxide: possible biomarker of carcinogenic potential?. Am J Respir Cell Mol Biol 43: 210-219.

12. Trouiller B, Reliene R, Westbrook A, Solaimani P, Schiestl RH (2009) Titanium dioxide nanoparticles induce DNA damage and genetic instability in vivo in mice. Cancer Res 69: 8784-8789.

13. Chen Z, Wang Y, Ba T, Li Y, Pu J, et al. (2014) Genotoxic evaluation of titanium dioxide nanoparticles in vivo and in vitro. Toxicol Lett 226: 314-319.

14. Bhattacharya K, Davoren M, Boertz J, Schins RP, Hoffmann E, et al. (2009) Titanium dioxide nanoparticles induce oxidative stress and DNA-adduct formation but not DNA-breakage in human lung cells. Part Fibre Toxicol 6: 17.

15. Theogaraj E, Riley S, Hughes L, Maier M, Kirkland D (2007) An investigation of the photo-clastogenic potential of ultrafine titanium dioxide particles. Mutat Res 634: 205-219.

16. Wan R, Mo Y, Feng L, Chien S, Tollerud DJ, et al. (2012) DNA damage caused by metal nanoparticles: involvement of oxidative stress and activation of ATM. Chem Res Toxicol 25: 1402-1411.

17. Warheit DB, Hoke RA, Finlay C, Donner EM, Reed KL, et al. (2007) Development of a base set of toxicity tests using ultrafine $\mathrm{TiO} 2$ particles as a component of nanoparticle risk management. Toxicol Lett 171: 99-110.
18. Kiss B, Bíró T, Czifra G, Tóth BI, Kertész Z, et al. (2008) Investigation of micronized titanium dioxide penetration in human skin xenografts and its effect on cellular functions of human skin-derived cells. Exp Dermatol 17: 659-667.

19. Pan Z, Lee W, Slutsky L, Clark RA, Pernodet N, et al. (2009) Adverse effects of titanium dioxide nanoparticles on human dermal fibroblasts and how to protect cells. Small 5: 511-520.

20. Sadrieh N, Wokovich AM, Gopee NV, Zheng J, Haines D, et al. (2010) Lack of significant dermal penetration of titanium dioxide from sunscreen formulations containing nano- and submicron-size TiO2 particles. Toxicol Sci 115: 156-166.

21. Wu J, Liu W, Xue C, Zhou S, Lan F, et al. (2009) Toxicity and penetration of $\mathrm{TiO} 2$ nanoparticles in hairless mice and porcine skin after subchronic dermal exposure. Toxicol Lett 191: 1-8.

22. Monteiro-Riviere NA, Wiench K, Landsiedel R, Schulte S, Inman AO, et al. (2011) Safety evaluation of sunscreen formulations containing titanium dioxide and zinc oxide nanoparticles in UVB sunburned skin: an in vitro and in vivo study. Toxicol Sci 123: 264-280

23. Shukla RK, Sharma V, Pandey AK, Singh S, Sultana S, et al. (2011) ROS mediated genotoxicity induced by titanium dioxide nanoparticles in human epidermal cells. Toxicol In Vitro 25: 231-241.

24. Prasad RY, Chastain PD, Nikolaishvili-Feinberg N, Smeester L, Kaufmann WK, et al. (2013) Titanium dioxide nanoparticles activate the ATM-Chk2 DNA damage response in human dermal fibroblasts. Nanotoxicology 7: 1111-1119.

25. Setyawati MI, Khoo PK, Eng BH, Xiong S, Zhao X, et al. (2013) Cytotoxic and genotoxic characterization of titanium dioxide, gadolinium oxide, and poly(lactic-co-glycolic acid) nanoparticles in human fibroblasts. J Biomed Mater Res A 101: 633-640.

26. Tucci P, Porta G, Agostini M, Dinsdale D, lavicoli I, et al. (2013) Metabolic effects of TiO2 nanoparticles, a common component of sunscreens and cosmetics, on human keratinocytes. Cell Death Dis 4: e549.

27. Dearfield KL, Cimino MC, McCarroll NE, Mauer I, Valcovic LR; US Environmental Protection Agency (2002) Genotoxicity risk assessment: a proposed classification strategy. Mutat Res 521: 121-135.

28. Vaziri H, Benchimol S (1998) Reconstitution of telomerase activity in norma human cells leads to elongation of telomeres and extended replicative life span. Curr Biol 8: 279-282.

29. Magdolenova Z, BilaniÄovÃ $i$ D, Pojana G, FjellsbÃ, LM, Hudecova A, et al (2012) Impact of agglomeration and different dispersions of titanium dioxide nanoparticles on the human related in vitro cytotoxicity and genotoxicity. J Environ Monit 14: 455-464

30. Tedja R, Lim M, Amal R, Marquis C (2012) Effects of serum adsorption on cellular uptake profile and consequent impact of titanium dioxide nanoparticles on human lung cell lines. ACS Nano 6: 4083-4093.

31. Ohtani B, Prieto-Mahaney OO, Li D, Abe R (2010) What is Degussa (Evonik) $\mathrm{P} 25$ ? Crystalline composition analysis, reconstruction from isolate pure particles and photocatalytic activity test. J Photochem Photobiol A 216:179-182.

32. Wise JP Sr, Wise SS, Little JE (2002) The cytotoxicity and genotoxicity of particulate and soluble hexavalent chromium in human lung cells. Mutat Res 517: 221-229.

33. Skin Cancer Foundation 2014.

34. Dickey JS, Redon CE, Nakamura AJ, Baird BJ, Sedelnikova OA, et al. (2009) H2AX: functional roles and potential applications. Chromosoma 118: 683-692.

35. Campisi J, d'Adda di Fagagna F (2007) Cellular senescence: when bad things happen to good cells. Nat Rev Mol Cell Biol 8: 729-740.

36. Franken NA, Rodermond HM, Stap J, Haveman J, van Bree C (2006) Clonogenic assay of cells in vitro. Nat Protoc 1: $2315-2319$

37. Wise SS, Elmore LW, Holt SE, Little JE, Antonucci PG, et al. (2004) Telomerasemediated lifespan extension of human bronchial cells does not affect hexavalen chromium-induced cytotoxicity or genotoxicity. Mol Cell Biochem 255: 103-111.

38. Wise JP Sr, Goodale BC, Wise SS, Craig GA, Pongan AF, et al. (2010) Silver nanospheres are cytotoxic and genotoxic to fish cells. Aquat Toxicol 97: 34-41.

39. Oberdörster G, Maynard A, Donaldson K, Castranova V, Fitzpatrick J, et al. (2005) Principles for characterizing the potential human health effects from exposure to nanomaterials: elements of a screening strategy. Part Fibre Toxicol 2: 8.

40. Warheit DB (2008) How meaningful are the results of nanotoxicity studies in the absence of adequate material characterization?. Toxicol Sci 101: 183-185. 